\title{
Fortalecimento do Sistema de Revisão por Pares
}

Há pouco tempo, estudei a possibilidade de realizar um seguro de vida com uma empresa estrangeira sediada nos EUA. Ela avaliaria minha saúde através de um médico conveniado, colheria uma amostra de sangue e - incrível - faria uma análise do meu DNA. Caso eles aprovassem minha bagagem genética, eu poderia realizar o seguro. Esse caso real exemplifica a grande tensão entre os interesses da população em geral e das companhias que provêem produtos e serviços. E nesse palco as revistas científicas estrelam um papel principal.

Um dos mais efusivos casos recentes dessa relação deu-se quando a justiça americana julgou o pedido da multinacional farmacêutica Pfizer para quebrar o sigilo editorial de duas revistas, o JAMA e os Annals of Internal Medicine.

Mais de 3.000 ações judiciais foram movidas contra a Pfizer, alegando que as medicações antiinflamatórias inibidoras da Cox-2, celecoxib e valdecoxib, possuem problemas semelhantes aos do Vioxx. Além disso, coscuvilhava-se que o laboratório farmacêutico sabia disso, tendo sido omisso ao não relatar o problema nas bulas dos produtos. O Vioxx foi tirado do mercado em 2004, por temor de que tivesse causado problemas cardíacos e acidentes vasculares cerebrais evitáveis em milhares de pessoas.

Assim, o objetivo da Pfizer, ao mover a ação contra as revistas, fora de se defender contra os processos, sendo que a empresa desejava tornar públicos os nomes de revisores anônimos que avaliam a qualidade de artigos científicos sub- metidos a esses periódicos.

$\mathrm{Na}$ sentença favorável às revistas, o juiz Arlander Keys defende o direito à confidencialidade no "peer review" (revisão por pares), a prática de enviar propostas de artigos a cientistas independentes, que os avaliam mediante a manutenção de seus nomes em sigilo. "A confidencialidade garantida das revisões permite aos revisores fazer críticas profissionais dos manuscritos, sem temerem potenciais reações dos autores", escreveu Keys.

A revisão por pares não é perfeita. Entretanto, ainda é o melhor sistema que possuímos para garantir um aprimoramento contínuo de procedimentos, materiais e medicamentos. Os interesses financeiros naturalmente geram pressões, às quais nós editores não podemos sucumbir. Entretanto, não devemos vê-los como inimigos, mas sim como uma força propelente ou um motor de combustão, que deve ser controlado para produzir os resultados pretendidos.

O presente número da Revista, como os demais, contém apenas artigos revisados por pares, com destaque para o estudo epidemiológico realizado por Silva Filho et al. sobre o padrão facial na dentadura decídua. Vários outros assuntos são abordados e os leitores se beneficiarão de sua análise.

Boa leitura.

Jorge Faber Editor 